\title{
Death Penalty in Indonesia: Revisiting the Debate Between the Retentionist and the Abolitionist
}

\author{
Abdul Jalil Salam* \\ Ar-Raniry State Islamic University, Indonesia \\ Zahlul Pasha Karim \\ Ar-Raniry State Islamic University, Indonesia
}

\begin{abstract}
Historically, Indonesia's death penalty does not originate from religious doctrine but a series of democratization processes agreed upon in the legislation. Amidst these processes, two competing opinions respond to Indonesia's death penalty: the retentionist and the abolitionist. These different approaches to address the death penalty, whether imposed or abolished, result in competing perspectives and arguments in regulatory and practical issues both in the national and international arena. This study aimed to revisit the death penalty discourse in Indonesia that opposes the human approach by assuming that the death penalty violates human rights. The data were analyzed in three steps, among other things, unitization, comparison, and conclusion. This study showed that the death penalty remains relevant to Indonesia despite the long struggle of its rejection. It concluded that Indonesia's imposition of the death penalty is regarded as worth defending, with specific and selective applications. The specific application means that the death penalty is applicable for corruptors, drug dealers, terrorists, gross human rights violators, and premeditated murders. Selective application means that a convict sentenced to death must be proven in court with a level of accuracy considered and accepted in law.
\end{abstract}

KEYWORDS: Death Penalty, Criminal Law, Right to Life, Indonesian Law.

Copyright $(2021$ by Author(s)

This work is licensed under a Creative Commons Attribution-ShareAlike 4.0 International License. All writings published in this journal are personal views of the authors and do not represent the views of this journal and the author's affiliated institutions.

\section{HOW TO CITE:}

Salam, Abdul Jalil \& Zahlul Pasha Karim, "Death Penalty in Indonesia: Revisiting the Debate Between the Retentionist and the Abolitionist" (2021) 8:1 Lentera Hukum 115-150. DOI: <https://doi.org/ 10.19184/ejlh.v8i1.20138>.

Submitted: 10/12/2020 Reviewed: 18/12/2020 Revised: 22/03/2021 Accepted: 01/04/2021

\footnotetext{
* Corresponding author’s e-mail: abduljalilsalam@ar-raniry.ac.id
} 


\section{INTRODUCTION}

One of the crucial discourses discussed on criminal law is the death penalty. Many countries such as Australia, Brazil, and France have abolished the death penalty. ${ }^{1}$ While other countries such as China, United States, and Indonesia remain to retain it. ${ }^{2}$ These different approaches to address the death penalty, whether imposed or abolished, result in competing perspectives and arguments in regulatory and practical issues both in the national and international arena.

The death penalty has emerged debates between those who oppose and agree with the meaning and nature of the penalty. ${ }^{3}$ For those who oppose (the abolitionist), the death penalty violates human rights, considered sadistic behavior. ${ }^{4}$ It lasted the psychological and social suffering to the convict and family envisaged as irreversible. Moreover, if there is an error in the death penalty decision, it cannot be corrected. As a result, the death penalty is often ineffective in reducing criminals or preventing similar acts. On the other hand, for those who defend (the retentionist), the death penalty should be blamed for persons who commit extraordinary crimes to fulfill justice which aims to repay someone's wrongdoing. This idea refers to the classic lex talionis (law of retaliation) found in almost all classical cultures and religions. ${ }^{5}$ The main reason the retentionist puts forward is that the primary purpose of the death penalty is intended to punish criminals. The convicts would no longer commit crimes against other persons and deter others from committing the same crimes. Adherents of

1 Syamsul Anwar Khoemaeni, "84 Negara Kecuali Indonesia yang Hapus Hukuman Mati”, (2015), online: Okenews <https://nasional.okezone.com/read/2015/04/28/ 337/1141582/84-negara-kecuali-indonesia-yang-hapus-hukuman-mati>.

2 BBC, "Negara mana yang masih menerapkan hukuman mati? Bagaimana dengan Indonesia?", (2018), online: BBC Nerws Indones <https://www.bbc.com/indonesia/ dunia-45859508>.

3 ICJR, "Hukuman Mati di Indonesia dari Masa Ke Masa", (2017), online: $<$ https://icjr.or.id/hukuman-mati-di-indonesia-dari-masa-ke-masa/>.

4 Muhammad Tahirulqadri, Islamic Philosophy of Punishments (Minhaj Quran Publication).

5 Nicola Lacey, State Punishment: Political Principal and Community Values (Routledge: Routledge University Press, 1994). 
this credence believe that God gave the government the right to carry out justice by imposing the death penalty. ${ }^{6}$

In Indonesia, the debate on the validity of the death penalty comes from the competing norms in existing regulations. These regulations recognize the death penalty, but they also retain and defend the right to life. Those who reject the death penalty argue that it does not give the perpetrators room for repentance. The death penalty results in a psychological and social suffering to the convict and family. Meanwhile, those who agree with the death penalty view the negative impression about it solely because it highlights humanity, regardless of the reason, purpose, intention, and effectiveness. They question constructive elements that are often missed in examining the death penalty in Indonesia.

Throughout history, the death penalty can be traced back to ancient times. In ancient Hebrew, for instance, there was a term known as Hammurabi's law. ${ }^{7}$ The main content of this law is that a loss must be redeemed with a fine or the exact value of retribution. It refers to an eye for an eye, a tooth for a tooth, and a life for a life. ${ }^{8}$ In Ancient Greece, the death penalty was commonly practiced. The case of Socrates executed with poisoned drinks became evident. Socrates was sentenced to death to practice a new religion/belief where his teachings were considered to influence young generations in their time negatively. ${ }^{9}$ Even in England in the $13^{\text {th }}$ century,

6 Imam Yahya, "Hukuman Mati dalam Perspektif Sejarah" (2013) 23:April Al-Ahkam J Pemikir Huk Islam 81-98.

7 Mir Zohair Husain \& Stephen E Costanza, "Code of Hammurabi" in Encycl Correct (John Wiley \& Sons, Inc., 2017) 1.

8 Marc Van De Mieroop, King Hammurabi of Babylon: A Biography (John Wiley and Sons, 2008). Mario Liverani, "Hammurabi of Babylon" in Anc East (Routledge, 2020) 264.Zohair Husain \& Costanza, supra note 7.

9 Mohammad Hatta, Mohammad Hatta (Jakarta: Tintamas, 1986); Richard Dargie, Ancient Greece Crime and Punishment (Compass Point Book Publisher, 2017). Based on Plato, people who rejected and insulted the gods commonly worshiped by the polis people were a form of unrighteousness and were threatened with the death penalty. Mohammad Hatta, Mohammad Hatta (Jakarta: Tintamas, 1986). Based on Plato's records, at that time, people who rejected and insulted the gods commonly worshiped by the people of a polis were a form of unrighteousness and were threatened with the death penalty. 
all crimes were punishable by death indiscriminately, except for petty fraud and theft of minor property. ${ }^{10}$

This study aimed to revisit the death penalty discourse in Indonesia that opposes the human approach by assuming that the death penalty violates human rights. Therefore, this analysis explored the constructive side that is often missed in examining the death penalty in Indonesia. It questioned why the death penalty in Indonesia remains to exist and is applied amidst these competing arguments?

\section{METHODS}

This study was qualitative under doctrinal research. The data were obtained from material and formal sources. Material data consisted of all statutory regulations that include the death penalty. In analyzing data, this study employed deductive, inductive, and comparative methods. The deductive method was used to obtain an overview of the death penalty in Indonesia. In contrast, the inductive method was aimed to obtain a comprehensive analysis regarding the debate in regulatory and practical aspects. In addition, the comparative method was mainly used to compare the arguments from each party, such as international and national law experts, including Islamic law experts and human rights activists that have different perspectives.

\section{THE DEATH PENALTY IN INDONESIA: A HISTORICAL RECORD}

In Indonesia, the Criminal Code (KUHP) still recognizes the death penalty outlined in Articles $140(3)$ and $340 .{ }^{11}$ These articles on capital

10 Barry Mitchell \& Julian V Roberts, "Sentencing for Murder: Exploring Public Knowledge and Public Opinion in England and Wales" (2012) 52:1 Br J Criminol 141-158.

11 Norval Morris \& David J Rothman, The Oxford History of the Prison: The Practice of Punishment in Western Society (Oxford: Oxford University Press, 1998). In Indonesia, Article 140(3) of the Criminal Code states: "If committed treason against life by planning to result in death, the punishment was the death penalty or life 
punishment were a manifestation of the criminal code written by the Dutch colonial government in 1918. It means that the enforcement of the death penalty in Indonesia was a legacy from the Dutch colonial power, which has not been completely corrected up to the present. While the death penalty is still enforced in Indonesia, Netherlands has abolished it since 1870, except for military crimes for a limited period. ${ }^{12}$

In 1854, the Dutch began to abolish capital punishment, namely crimes using a method claimed as "torture" because it was considered useless. ${ }^{13}$ Considering the practice of punishment is relatively "harsh," causing deep trauma and imposing human dignity, the Dutch criminal law began to practice corporal punishment after adopting the French Code de Penal from 1811-1886. ${ }^{14}$ After the Dutch independence from France, applying the punishment of expulsion or disposal is not applied even though it exists in their criminal law. ${ }^{15}$ The Netherlands finally abolished the death penalty for all crimes after a total amendment was made to its Constitution on February 17, 1983. It was expressly stated (by their constitutional judges) that the death penalty could not be imposed. ${ }^{16}$ The consequence is the obligation to harmonize laws and regulations under it, including the elimination of the death penalty in military criminal law. ${ }^{17}$ The abolition of the death penalty did not apply to law enforcement in the Dutch East

imprisonment or a maximum temporary imprisonment of twenty years." Meanwhile, Article 340 outlines: "Anyone who deliberately and with a plan seized the life of another person was threatened with planned murder, with the death penalty or life imprisonment or a maximum period of twenty years."

12 Yesmil Anwar, Pembaruan Hukum Pidana: Reformasi Hukum (Jakarta: Penerbit Grasindo, 2018).

13 Austin Sarat \& Jürgen Martschukat, Is the death penalty dying?: European and American perspectives (Cambridge University Press, 2011).

14 Jack P Gibbs, "The Death Penalty, Retribution and Penal Policy" (1978) 69:3 J Crim Law Criminol 1973- 291. Christian Reitzenstein-Ronning, "Performing justice: the penal code of Constantine the Great" (2015) 265-288.

15 BN Marbun, Kamus Hukum Indonesia (Jakarta: Pustaka Sinar Harapan, 2016).

16 Andrew Hammel, Ending the death penalty: The European experience in global perspective (Palgrave Macmillan, 2010).

17 William Schabas, The Abolition of the Death Penalty in International Law (Cambridge: Cambridge University Press, 2002). 
Indies (now Indonesia), as it was used as an instrument to suppress the independence movement. ${ }^{18}$

After Indonesia's independence, the Criminal Code, which was formerly known as Wetboek van Strafrecht (WvS), was declared valid based on Article II of the Transitional Rules of the 1945 Constitution and Law 01/1946 on the application of WvS to the Criminal Code. The application of the Criminal Code has not experienced any amendments compared to the application during the colonial era. In its later development, the death penalty is not only regulated in the Criminal Code as part of a general criminal act, but the government also issues laws and regulations that provide a specific death penalty.

$\begin{array}{ll}\text { Existing Laws } & \text { Description / About } \\ \text { Criminal Code } & \text { a. Treason } \\ \text { b. Inviting or inciting other countries to attack RI } \\ \text { c. Killing the Head of a Friendly Country } \\ \text { d. Premeditated murder } \\ \text { e. Violent theft by two or more friends at night by } \\ \text { destroying houses resulting in serious injury or death } \\ \text { f. Piracy in the sea, shore, and river resulting the person } \\ \text { dying } \\ \text { g. Encourage rebellion or rioting of workers towards state } \\ \text { defense companies during the wars } \\ \text { h. Violent extortion } \\ \text { Firearms } \\ \text { The authority of the Attorney General / Attorney General } \\ \text { Presidential Decree } \\ \text { of the Army in aggravating the threat of death penalty for } \\ \text { crimes that endanger the implementation of food and } \\ \text { clothing equipment }\end{array}$

Government Regulation in Lieu of Law 21/1959

Aggravating the threat of punishment for economic crimes

18 The application of Article 104 of the Criminal Code was used to perpetuate political repression. The occupation government also used the threat of the death penalty to protect the interests of military industry in periods of war, especially against acts of labor resistance. See Marwati Juned Pusponegoro et al, Sejarab Nasional Indonesia: Kemunculan Penjajahan di Indonesia (Jakarta: Penerbit PT Balai Pustaka, 2008). 
Law 11/PNPS/1963

Law 04/1976

Law 05/1997

Law 22/1997

Law 31/1999

Law 26/2000

Law $15 / 2003$
Eradication of Subversion Activities (has been revoked)

Amendments and additions to several articles in the

Criminal Code are related to the expansion of the

legislation on aviation crime and aviation

facilities/infrastructure

Psychotropics

Narcotics

Corruption Eradication

Human Rights Court

Combating Criminal Acts of Terrorism

Table I: Indonesia's Legislation Containing Death Penalties ${ }^{19}$

Under the 1950 Provisional Constitution, known as the liberal democracy period (1950-1959), the parliament and government issue a statutory regulation that threatens the death penalty, namely Emergency Law 12/1951 concerning Firearms, promulgated on September 4, 1951. During the Guided Democracy (1959-1966), the legal products that regulate the application of the death penalty continue to increase. The government issued Presidential Decree 05/1959 on the Authority of the Attorney General/Attorney General of the Army to aggravate the threat of punishment for crimes that endanger food and clothing equipment implementation, promulgated on July 27, 1959. Besides, the government also issues a Government Regulation in Lieu of Law 21/1959, which aggravates the threat of punishment for economic crimes, promulgated on November 16, 1959. In 1963, the government issued Law 11/PNPS/1963 on the Eradication of the Criminal Act of Subversion, which was promulgated on October 16, 1963. At that time, the government utilized this law to silence Sukarno's political opponents by throwing them in prison without court proceedings. Subsequently, the government issued Law 31/PNPS/1964 on Fundamental Provisions of Atomic Energy. ${ }^{20}$

${ }^{19}$ Kontras Research and Development and from various sources.

20 In development, this law was replaced by Law 10/1997 on Nuclear Power, and the threat of the death penalty was replaced by life imprisonment. See Niniek Suparni, Tindak Pidana Subversi: Suatu Tinjauan Yuridis (Jakarta: Sinar Grafika, 1991). 
In this era, the government issued Law 02/PNPS/1964 on procedures for implementing the death penalty in the military court and the general court. In the law, the convict of the death penalty was carried out by shot dead. Previously, there were never any regulations regarding how executions should be carried out except for the law practice of shooting to death for military crimes, which was also a legacy of Dutch colonialism. ${ }^{21}$

The replacement of Sukarno's leadership by Suharto's New Order did not influence the death penalty enforcement in Indonesia. At that time, persons accused of being involved in the Indonesian Communist Party movement were also threatened by the death penalty. To distinguish it from the Guided Order and to attract public sympathy at that time, the New Order government employed the law on eradicating subversion, which used the death penalty to accuse the perpetrators of corruption. However, no perpetrator was sentenced to the death penalty. ${ }^{22}$

In February 2020, six persons were sentenced to death for committing drug crimes and premeditated murder. ${ }^{23}$ It can be tracked from which Suharto government adopted a populist policy through Narcotics Law 22/1997 and Psychotropics Law 05/1997. This law was a direct reaction to the rampant trafficking of drug smuggling in the 1990s. The government's inability to tackle drug trafficking made them consider it is necessary to include the death penalty. ${ }^{24}$ The initiation of the reform agenda after the fall of the Suharto regime on May 21, 1998, does not make the death penalty disappear from Indonesia's main criminal ranks. However, the Antisubversive Law was eventually abolished due to demands from various circles of society. One of the urgent reform agendas is eradicating corruption, collusion, and nepotism to form a more authoritative and cleaner government. Therefore, it is not surprising that Habibie's

21 Undang-Undang No. 2/PNPS/1964 tentang Tata Cara Pelaksanaan Pidana Mati.

22 Badan Pekerja Kontras, Praktek Hukuman Mati di Indonesia: Laporan Hasil Penelitian (Jakarta: Kontras, 2017).

23 Andi Saputra, "6 Orang Dihukum Mati Sepanjang Februari 2020, Ada yang Nangis Mewek", (2020), online: Detiknews <https://news.detik.com/berita/d-4920456/6orang-dihukum-mati-sepanjang-februari-2020-ada-yang-nangis-mewek>.

24 Titon Slamet Kurnia, Hak atas Derajat Kesehatan Optimal Sebagai HAM di Indonesia (Bandung: Penerbit Alumni, 2017). 
government was relatively short but productive in enacting laws, such as by issuing Law 31/1999 on Eradication of Corruption Crimes, replacing Law 3/1971. This law expressly threatens the perpetrators of corruption with the death penalty. ${ }^{25}$ Even more phenomenal, Human Rights Courts Law $26 / 2000$ includes the death penalty. Even though it is no longer recognized and permitted in international practice, as the Rome Statute of International Criminal Court (ICC) jointly recognized as a reference to international standards to impose penalties for perpetrators of gross violations of human rights. ${ }^{26}$

Finally, the government also issued a Government Regulation in Lieu of Law 01/2002 on the Eradication of Terrorism on October 18, 2002. The emergence of the Government Regulation in Lieu of Law is the government's quick response to the Bali Bombing tragedy on October 12, 2002. The death penalty threat is aimed at the perpetrators of criminal acts of terrorism. Despite many criticisms of the dangers of this law, the government remains consistent. Furthermore, DPR also supports this position which consensually ratifies the Government Regulation in Lieu of Law into Law 15/2003 on March 6, 2003. ${ }^{27}$

\section{A. Criminal Punishment in Indonesia}

The term criminal law is part of the overall law applicable in a country that lays down the following foundations and rules; ${ }^{28}$ First, determine the actions that should not be done, accompanied by threats or sanctions in the form of certain crimes for those who violate the prohibition. Second, determine when and in what cases those violated these prohibitions can be imposed or sentenced. Third, determine how to impose criminal charges

25 Krisna Harahap, Pemberantasan Korupsi, Jalan Tiada Ujung (Penerbit Grafitri, 2016).; Badan Pekerja Kontras, supra note 22.

${ }^{26}$ Artidjo Alkostar, Pengadilan HAM, Indonesia dan Peradaban (Yogyakarta: PUSHAMM-UII, 2014).

27 Spectrum Institute, Terorisme Ditengah Arus Global Demokrasi (Penerbit Spectrum, 2016).

28 Eddy OS Hiariej, Prinsip-Prinsip Hukum Pidana (Yogyakarta: Cahaya Atma Pustaka, 2016). 
on people who are suspected of violating the prohibition..$^{29}$ Meanwhile, criminal law aims to impose sanctions or retaliation against the criminal act, besides preventing criminal acts and maintaining public order. ${ }^{30}$

David J. Cornwell interprets punishment as an unpleasant feeling or misery imposed by the judge with a verdict on a person who violated the criminal law. ${ }^{31}$ Meanwhile, according to David C. Brody, punishments are punished by the dominant agency, delegated to one or several individuals as uncomfortable, and those are not usually bestowed daily. ${ }^{32}$ Meanwhile, Christopher Clarkson considers that punishment is a form of suffering, sorrow, or anything physically unpleasant (bodily) given to someone because of actions found guilty legally. ${ }^{33}$ Thus, the punishment is torture or suffering imposed explicitly on people who violate the norms or rules of criminal law through the mechanism of a judge's decision.

29 Jerome Hall, General Principal of Criminal Law (The Lawbook Exchange Ltd. Publisher, 2015).

30 William Wilson, Criminal Law: Doctrine and Theory (Longman: Longman Publisher, 2003). In general, there are three theories about criminal law. First, the theory of retaliation (absolute) taught that the primary purpose of imposing criminal law on the criminal perpetrators is to retaliate for the criminal act. Second, the relative or objective theory stated that punishment was not to take revenge on the perpetrator of a criminal act but has certain goals that were more useful to human life, namely to appease society and prevent the crime. Third, the combined theory (verenegings theorieen), compromising even combining the two theories above. See Sofjan Sastrawidjaja, Hukum Pidana: Asas Hukum Pidana sampai Dengan Alasan Peniadaan Pidana (Bandung: Amrico, 1995). Article 54 of the RKUHP 1997/1998 stated that punishment was intended to prevent committing a crime by enforcing legal norms to protect the community. It also resolves conflicts caused by criminal acts, restores balance and bring a sense of peace to society, socialize the convict by guiding them so that they become a good, helpful person, and liberated the guilt of the convict; Lili Rasjidi, Dasar-dasar Filsafat Hukum (Bandung: Citra Aditya Bakti, 1993).

31 David J Cornwell \& Tony Cameron, Criminal Punishment and Restorative Justice: Past, Present, and Future Perspective (United States: Waterside Press, 2016).

32 David CBrody, James R Acker \& Wayne A Logan, Criminal Law (US: Johns and Bartlett Publishers, 2001). Wiryono Prodjodikoro, Asas-Asas Hukum Pidana di Indonesia (Bandung: Eresco, 1989).

33 Christoper MV Clarkson, Understanding Criminal Law (Sweet and Maxwell Publisher, 2005). 
According to Benyamin and Curzon, the purpose of punishment can be compiled into four parts, namely: revenge/absolute, expiation, deterrent, and rehabilitation. ${ }^{34}$ In Indonesia, the Criminal Code adopted two types of punishment. They are the main and additional punishments. The main penalties are known in the Criminal Code as the death penalty, imprisonment, ${ }^{35}$ imprisonment penalty, ${ }^{36}$ and fine. ${ }^{37}$ Meanwhile, additional penalties can be in the form of revocation of certain rights, confiscation of certain items, and a judge's decision. ${ }^{38}$

\section{B. Provision of Right to Life in Indonesia}

The 1945 Constitution guarantees the right to life. ${ }^{39}$ Also, Human Rights Law 39/1999 outlines the right to life. Article 9 of Human Rights Law states that everyone has the right to life, maintain life, and improve the living standard. Article 4 of this Law includes the right to life as the nonderogable rights. This right cannot be diminished under any circumstances

34 Benyamin and Others, Prisons or Crime Prevention (England: Little Blue Book CO, 1977).

35 The sentence of placement in a prison house employs perpetrators. The imprisonment recognizes the lowest and the highest limit. The lowest limit is one day, and the highest limit is fifteen years. This limit can be extended to twenty years for particular circumstances (Article 12).

36 The imprisonment penalty is at least one day, and the maximum is one year. However, this period can be increased to one year and four months because of a combination of crimes or recurring circumstances to commit a crime (Article 18).

37 The penalty fine for compensation in the form of assets at least twenty-five cents (for the size at the time this law was made and will always be adjusted to the conditions, time, place, and other conditions for the adjustment referred/conversion). In this case, if a penalty fine is imposed, then the fine is not paid. It is replaced by imprisonment. Replacement confinement for at least one day and a maximum of six months, considering every half of Rupiah (can be converted), one day. The imprisonment detention can be eight months. Its maximum fine is increased because there is a combination of crimes or repeated crimes (Article 30).

38 Constitutional Court Decision Number 2-3/PUU-V/2007; See also Moh. Mahfudh MD, Membangun Politik Hukum, Menegakkan Konstitusi (Jakarta: LP3ES, 2006).

39 See Article 28A of the 1945 Constitution: "The right to life, the right not to be tortured, the right to freedom of thought and conscience, the right to religion, the right not to be enslaved, the right to be recognized as a person in front of the law, and the right not to be prosecuted based on retroactive law is a human right that cannot be reduced under any circumstances." 
by anyone. It is in line with international provisions that govern similar provisions. ${ }^{40}$ However, in Decision 02-03/PUU-V/2007, the Constitutional Court asserted that the right to life is not absolute, which means that the death penalty by referring to Narcotics Law 27/1997 does not infringe the 1945 Constitution. ${ }^{41}$ This court argument was based on several statements that all rights contained in the constitution can be limited in effect, including the right to life. Besides, the Constitutional Court argued that Article 28J as the last article that outlines human rights in the 1945 Constitution, provides an interpretation that it can limit constitutional rights enumerated from Articles 28A to 28I of the 1945 Constitution. ${ }^{42}$ The Constitutional Court's decision is consistent with the previous decision in the case of Abilio Soares. ${ }^{43}$ The Court interpreted that the right to life was not absolute. Instead, it remains to refer to international instruments that recognize the right to life. For instance, the International Covenant on Civil and Political Rights (ICCPR) permits the death penalty with certain limitations. ${ }^{44}$

The Constitutional Court argued the imposition of the death penalty for narcotics crimes that does not violate the restrictive provision in the ICCPR regarding the imposition of the death penalty. The Constitutional Court argued the phrase 'the most serious crimes' should be read with the 'appropriate the applicable law at the commission of the crime. ${ }^{145}$ The

40 Articles 4 and 9 of the Human Rights Law 39/1999; See also Romli Atmasasmita \& Agus Takariawan, Reformasi Hukum, Hak Asasi Manusia dan Penegakan Hukum (Mandar Maju, 2011).

41 Constitutional Court Decision Number 2-3/PUU-V/2007; Moh. Mahfud M.D., supra note 38.

42 Ibid.

43 Abilio Soares requested a judicial review of Article 43 of the Human Rights Courts Law 26/2000 and was decided by the Constitutional Court through Decision Number 065/PUU-II/2004. In the decision, the Constitutional Court also has a stand that the right not to be prosecuted by retroactive law, it is also part of nonderogable rights is also not absolute.

${ }_{44}$ Constitutional Court Decision Number 2-3/PUU-V/2007; Moh. Mahfud M.D., supra note 38.

45 Manfred Nowak, United Nation Covenant on Civil and Political Rights, ICCPR Commentary (Leiden: N.P. Engel Publisher, 2005).; Banding Putusan Mahkamah Konstitusi, Nomor 2-3/PUU-V/2007. 
Constitutional Court states that whether the provisions containing crimes with the death penalty in Narcotics Law 22/2007 are included in the most serious crimes linked to the laws that apply to these crimes both nationally and internationally. The Constitutional Court stated that at the international level, the applicable law is the UN Convention against Illicit Traffic in Narcotic Drugs and Psychotropic Substances 1988 (Narcotics and Psychotropic Substances Convention), where Indonesia is a party to the convention. ${ }^{46}$

This convention stated that narcotics crimes are included in the most serious crimes. Therefore, the Constitutional Court argued that narcotics crimes as severe crimes in the convention could be 'equalized' with the most serious crimes according to Article 6 of the ICCPR. Furthermore, the Constitutional Court argues no international obligations that Indonesia violates by imposing the death penalty for drug crimes. ${ }^{47}$

\section{Competing Arguments on the Death Penalty}

Historically, the imposition of the death penalty has been a classic debate dealt with utilitarianism, retributivism, and abolitionism. Utilitarianism focuses on the future consequences of punishment. This theory is a limitedly applied form of the basic principle of utilitarian ethics, which states that an action can be justified morally as long as the consequences are good (mashlahah) for many people. ${ }^{48}$ The calculated positive consequences of an action are the sole criterion for its justification. ${ }^{49}$ The punishment as an act against a criminal can be justified morally. It is not because the convicted person is guilty of breaking the law, but the punishment has

46 Constitutional Court Decision Number 2-3/PUU-V/2007 Moh. Mahfud M.D., supra note 38.

47 Ibid.

48 Asep Saepullah, “Konsep Utilitarianisme John Stuart Mill: Relevansinya terhadap Ilmu-ilmu atau Pemikiran Keislaman” (2020) 11:2 Aqlania J Filsafat Dan Teol Islam 243-261. Mohammad Maiwan, "Memahami Teori-Teori Etika: Cakrawala dan Pandangan" (2018) J Uiversitas Negeri Jkt 193-215.

49 However, the emergence of a negative impression about the death penalty can only be seen from one aspect, namely humanity according to the modern world's standards, regardless of the reasons, aims, objectives, and effectiveness. 
positive consequences for the convicted person. For example, the punishment could deter the convicted persons so that they would never repeat their mistakes. Thus, the punishment can muffle and reduce feelings of revenge on victims and their families, and punishment becomes a deterrent to crime in society. ${ }^{50}$

On the other hand, the retributivist group seeks a basis for punishment by looking to the past, focusing on crimes. According to this theory, punishment is applied because the perpetrator must accept it for the sake of a mistake. ${ }^{51}$ In other words, the moral consideration lies in the fairness of a punishment. Therefore, the punishment can be justified morally, as long as the punishment has been proven. Every person who has been proven guilty and got punishment is a correct act. Therefore it is justified to be punished. Crimes that have been proven legally and formally are the only basis why state institutions have the right and obligation to punish the perpetrators. Justice means that the punishment must be balanced with the level of wrongdoing. ${ }^{52}$

Two figures who are influential in the flow of retributivism are Immanuel Kant and Hegel. Kant said that "Punishment can never be given as a means to achieve any other good, whether it concerns the criminal himself or society. In all circumstances, punishment can be imposed on a person simply because the convicted individual is a guilty criminal". ${ }^{53}$ Meanwhile, Hegel considered punishment as an expression of the general will.54 For Hegel, acting against the law is to oppose general will (the true and "absolute" free will of the subject). ${ }^{55}$ Only, in its evil act, true free will is resisted and defeated by arbitrary freedom. Therefore, criminal action injures and afflicts other people (victims) and opposes the general will,

50 Wilson, supra note 30. Banding Barda Nawawi Arief, Kebijakan dalam Penanggulangan Kejahatan dengan Pidana Penjara (Semarang: Ananta, 1994).

51 Iwan Darmawan, "Perkembangan dan Pergeseran Pemidanaan" (2015) 1:2 Palar Pakuan Law Rev. Usman, "Analisis Perkembangan Teori Hukum Pidana" J Ilmu Huk.

52 Leo Zaibert, Punishment and Retribution (Ashgate: Ashgate Publishing Ltd, 2016).

53 Cavender Gray, "Justice, Sanctioning, and the Justice Model" (1984) Criminology.

54 Thom Brooks, Hegel's Philosophy of Right (Wiley-Blackwell, 2011).

55 Georg Wilhelm Fredrich Hegel, Hegel: Elements of the Philosophy of Right (Cambridge University Press, 1991). 
which indirectly means treating other people improperly and more than that because it has opposed and hurt the general will. Therefore, punishment is justified not only for the recovery of the victim. ${ }^{56}$ The legal debate on the validity of capital punishment comes from existing regulations, which on the one hand still recognize the death penalty and on the other hand recognize and defend the right to life. Laws that have been violated but also in the interests of the perpetrator. However, not a few legal experts have put forward the discourse to abolish the application of the death penalty in Indonesia.

\section{The Opponent' Statements}

The groups who oppose the death penalty are those who adhere to the concept of rehabilitation. They completely reject the death penalty, for whatever reasons. The argument may come that justice is considered a reason for the death penalty, punishing a killer with the same reprisal. Consequently, the death penalty is envisaged as an unfair act against criminals who need an opportunity to change, repent, improve, and renew themselves. It contravenes the purpose of justice, where punishment is not to punish but renew. ${ }^{57}$

The abolitionist emerged that put forward the attitude of forgiveness to the criminals with humanitarian consideration ${ }^{58}$ The abolitionist argued that the death penalty could not be justified because it contradicts the right to life, which is the most fundamental, absolute, and noble right possessed by every human being, which must be respected even by a murderer. ${ }^{59}$ The abolitionist opposed the utilitarian view that the death penalty as a form of deterrence is ineffective. How could a person who died because he had been executed would be a deterrent? However, if the death penalty is

56 Zaibert, supra note 52.,: Bambang Poernomo, Asas-asas Hukum Pidana (Yogyakarta: Ghalia Indonesia, 1995).

57 JJ Tobias, Crimes and Industrial Society in the Nineteenth Century (England: Penguin Book Press, 1973).

58 Risman Dosen et al, "Polemik Pemidanaan (Kontroversi Faham Abolisionis Dan Retensionis)” (2018) 1:2 J Syariah Huk Islam 158-165.

59 Ibid. 
replaced by a life sentence, of course, the detention aspect will be effective. Another argument is that the death penalty, which is considered contrary to human rights, should not be used as a means of deterrence or as retribution. ${ }^{60}$

Several implications have caused many legal and human rights experts in Indonesia to reject the death penalty. ${ }^{61}$ First, it is considered cruel and terrible, reminiscent of the law of the jungle. Second, it is unable to eradicate a crime or cannot prevent someone from committing a crime. Third, the execution of the death penalty is perpetual, irrevocable if it does not have a solid basis in the future. Fourth, contrary to the person's freedom (private), human life is essential personal property and cannot be disturbed by others. They show the frequency and quality of awareness and participation of countries worldwide to abolish the death penalty through several regional and international human rights instruments.

No. Instrument

Information

1. Second Additional Protocol to the CivilPolitical Covenant, 1989

2. Protocol to the American Convention on Human Rights Abolition of the Death Penalty, 1990

3. Protocol No.6 to the European Convention on Human Rights 1983 crimes"
Number of

Countries

Abolition of the death penalty for all
crimes. It still allows reservations to
apply the death penalty in peacetime
for the category "most serious military
crimes"

Abolition of the death penalty for all crimes. It still allows reservations to apply the death penalty in peacetime for the category "most serious military

Abolition of the death penalty for all crimes in peacetime. plus one signatory country.
59 countries plus 34 signatory countries.

Eight countries plus one signatory country.

\section{5 countries}

60 Schabas, supra note 17.

${ }^{61}$ Muhammad Hatta, "Perdebatan Hukuman Mati di Indonesia: Suatu Kajian Perbandingan Hukum Islam dengan Hukum Pidana Indonesia" (2012) 36:2 MIQOT J Ilmu-Ilmu Keislam. Maria Anna Muryani \& Noor Rosyida, "The Concept of Death Penalty in a Pancasila State (Perspective of Official Religion in Indonesia)" (2020) 2:2 Walisongo Law Rev Walrev 131. 
4. Protocol No. 13

European

Convention on

Human Rights, 2002
Abolition of the death penalty in all 37 countries

situations, including during

peacetime. plus seven

signatory

countries.

Table II: International and Regional Human Rights Instruments on Abolition of the Death Penalties ${ }^{62}$

Those who disagree with the death penalty in Indonesia stated that: ${ }^{63}$ First, the historical threat of capital punishment does not originate from Pancasila because the Indonesian Criminal Code is inherited from the Netherlands. Even the Netherlands has abolished the death penalty. Second, the death penalty (which is premeditated murder) is dangerous if the convict is innocent. It is impossible for any reparations once people have been executed. Third, around the world, the death penalty has not proven capable of catching potential big criminals. ${ }^{64}$ Fifth, the perpetrator of a crime (murder, for example) is sometimes the main witness needed to solve a crime. In other words, the perpetrator of the murder could be the agent or accomplice of the mastermind of the crime or the intellectual actor behind the crime he committed. So, killing the murderer in this context will bury the opportunity to uncover a crime case. ${ }^{65}$

The results of several studies on crime did not show a positive correlation between the death penalty and a reduction in crime rates. Some studies even revealed that those convicted of murder-including those who

${ }^{62}$ Kontras Research and Development and from various sources

${ }^{63}$ Hatta, supra note 61. Nur Afif Ardani, Sulfi Amalia \& Rooseno Hertanto, "Relativisme Budaya Dalam Hak Asasi Manusia" (2017) 14:1 30-46.

${ }^{64}$ Casten Ankar, Determinants of the Death Penalty; Comparative Study of the World (London: Routledge Press, 2014). Talking about the deterrent effect, the existence of the death penalty does not necessarily eliminate or minimize crimes, such as drugs, serial killers, and others, because people are not afraid of the death penalty. Instead, they are afraid of starvation or economic deprivation, losing someone, protecting themselves, or other reasons to save themselves rather than thinking about the consequences.

65 Abdullah Yazid, "Meninjau Ulang Hukuman Mati”, (2019), online: <http://www. averroes.or.id/opinion/meninjau-ulang-hukuman-mati.html>. 
planned - did not usually commit violence in prison. Likewise, after leaving prison, they no longer commit the same violence or crime. On the other hand, some experts have criticized that a legal perspective cannot reach the complexities of violent crime cases with some causes. First, the victim collaborates with the perpetrator of the crime. Second, the individual is both the victim and the perpetrator. Third, persons who appear to be victims are the perpetrators. ${ }^{66}$

The rejection of the death penalty addresses rational, moral, and religious considerations and conscience as a civilized human being. To be sure, rational considerations are subjective. However, public perception does not support the execution of the death penalty based on haphazard trials, hatred considerations, and resentment. Thus, it is quite contrary to common sense or reason. ${ }^{67}$ Moral and religious considerations are completely ignored in capital punishment decisions. Morally, humans are noble creatures with a conscience. Although they tend to do evil, they are human beings who become moral subjects whose lives must be respected. Religion taught that human life comes from God, so only God has the right to end life. No one has the right to demean someone's dignity based on any differences, whether race, religion, social level of life, including differences in behavior. ${ }^{68}$ Although the death penalty is still attached to several national laws, the death penalty is considered to negate the 1945 Constitution. ${ }^{69}$ Some people consider the death penalty to be quite contrary to the Human Rights Law 39/1999 because it deliberately takes away the right to life of a human. ${ }^{70}$ Therefore, as the subject with the highest authority in implementing the law, the state must understand this case. The government is obliged to re-examine laws that contradict one another.

66 Evan J Mandery, Capital Punishment: A Balanced Examination (Jones and Bartlett Publishers, 2014). Arief, supra note 50.

67 Mandery, supra note 66.

68 Moreover, all religions believe in the importance of repentance and forgiveness. If God, who is the source of life, is not arbitrary to humans and other creatures, why do other humans act arbitrarily to the lives of others? JE Sahetapy, Suatu Studi Khusus Mengenai Ancaman Pidana Mati terhadap Pembunuan Berencana.

${ }^{69}$ Ibid.

70 Law 02/PNPS/1964 on the death penalty procedure, supra note 21.as a means of justification outlines that the state deliberately and consciously takes a person's life. 


\section{The Proponent' Statements}

One of the groups that support the death penalty is the reconstructionists (theonomists). They stated that the death penalty should be imposed on those who have committed significant crimes. According to them, justice aims to repay human wrongdoing. It was based on the classic lex talionis (law of retaliation) found in almost all classical cultures and religions. ${ }^{71}$ In general, adherents of reconstruction explained that society must be restructured (reconstructed) based on their respective religious laws. ${ }^{72}$

The other group is the retribution group. Adherents of this group viewed that the primary purpose of the death penalty is to punish the perpetrator of a crime so that the person no longer commits a crime and that others become afraid of committing the same crime. ${ }^{73}$ Adherents of this idea believe that God gave the government the right (authority) to carry out justice by imposing the death penalty. However, on closer examination, each type of penalty contains an element of cruelty. ${ }^{74}$ The worries of the opponent group on the mistake of the judge's decision also apply to other sentences. For example, if someone was sentenced to ten years in prison, they found new evidence (novum) showing an error in the judge's decision, then Can the verdict be changed? If thoroughness and justice can be carried out. Errors in determining the death penalty will likely be relatively avoided.

Regarding allegations of torture, sadism, and humiliation of dignity in executing the death penalty, the death penalty proponent groups provide

${ }^{71}$ Lacey, supra note 5. In cultural language, the law of retaliation is known as law: "tooth for tooth, eyes for eyes."

72 This understanding is commonly referred to as a theonomist because it refers to God's Law.

${ }^{73}$ M Abdul Kholiq \& Ari Wibowo, "Penerapan Teori Tujuan Pemidanaan dalam Perkara Kekerasan" (2016) 23:2 186-205. Eva Achjani Zulfa, "Pergeseran Paradigma Pemidanaan di Indonesia" (2017) 36:3 J Huk Pembang 389. Marcus Priyo Gunarto, "Sikap Memidana yang Berorientasi pada Tujuan Pemidanaan" (2009) 21:1 Mimb Huk.

${ }^{74}$ Considering that everyone has no right to determine justice by themselves, the administration of justice is carried out by the government, so the government has the right to enforce justice by executing the death penalty for serious criminals. Roger $G$ Hood, "The Death Penalty: A Worldwide Perspective" 225. 
arguments. First, causing a feeling of pain is presented in the execution of the death penalty because someone is alive and well, then lifeless. Second, pain or a painful process is different from torture, even though they both experience the same condition, namely pain. Pain is an unpleasant condition (in terms of health) experienced by a person. ${ }^{75}$ Third, illness or the process of illness will be experienced by the death row inmates who were executed deliberately in any way. During or after the execution, the pain or sickness process is not an act of torture and is not intended to torture, but rather as a natural death process. ${ }^{76}$

The understanding of human rights must be placed proportionally because it has a limitation, as stated by the proponent group. The right to life of sadistic killers, massacres, drug kingpin, and drug producers is no longer a matter of question compared to the lives and rights of the millions of people who could be a victim to their crimes. ${ }^{77} \mathrm{~A}$ person who has lost another person's life without rights shows that he/she no longer considers the legal consequences, including the right to life of the victim. The victim also has the right to live like the murderer. Therefore, it is natural for people who kill intentionally. Their life must also be removed from the life of society.

Bichon van Ysselmonde, as quoted by Widodo, agreed to keep the death penalty. ${ }^{78}$ He stated that the threat and the death penalty must exist in every country and an orderly society, both viewed from lawfulness and cannot be eliminated. De Savornin Lohman said, "In the Book of the Law, a country must recognize that the state has the right to kill the life of criminals who do not pay attention to zedewet at all. The criminal law is

75 Wawan H Purwanto, Kontroversi Seputar Hukuman Mati Amrozi CS (Jakarta: Cipta Mandiri Bangsa, 2008).,: See MK decision number 21/PUU-VI/2008 tentang Pengujian Undang-undang tentang Tatacara Pelaksanaan Eksekusi Mati.

76 MK decision number 21/PUU-VI/2008 tentang Pengujian Undang-undang tentang Tatacara Pelaksanaan Eksekusi Mati.

77 Supardi, Kajian Kritis Pro dan Kontra Pelaksanaan Hukuman Mati Di Indonesia, Khususnya Terhadap Kejahatan Narkoba (Jakarta: Badan Narkotika Nasional Republik Indonesia, 2015).

78 Rusman Widodo, "Konfigurasi Pertarungan Abolisionisme Versus Retensionisme dalam Diskursus Keberadaan Lembaga Pidana Mati di Tingkat Global dan Nasional" (2012) 8 J Komnas HAM 315-348. 
none other than the law of retaliation (the rule of torture version of the Malaysian state law)." ${ }^{179}$

Criminologists Lombroso and Garofalo stated that the death penalty is a fundamental tool that must be presented in society to eliminate individuals who commit serious crimes. ${ }^{80}$ The death penalty is a radical attempt to eliminate people who are beyond repair. ${ }^{81}$

According to Achmad Ali, an expert on Indonesian criminal law, the death penalty is still needed, especially in Indonesia, but must be specifically and selectively applied. Specific means that the death penalty is applied to perpetrators of serious crimes, such as corruptors, drug kingpins, terrorists, serious human rights violators, and premeditated murder. The means of selection is that the convict sentenced to death must have been proven convincingly in court. ${ }^{82}$ Ali argues that the amended 1945 Constitution does not prohibit the death penalty. Article 28I(1) states that the right to life, the right not to be tortured, the right to freedom of thought and conscience, the right to religion, the right not to be enslaved, the right to be recognized as a person before the law, and the right not to be prosecuted. Thus, based on retroactive law are human rights cannot be reduced under any circumstances. However, Article 28I(1) must be complemented by understanding Article 28J(2), which outlines that in exercising his rights and freedoms, every person is obliged to obey the restrictions established by law to ensure recognition, respect for the rights

79 MK decision number 21/PUU-VI/2008; UII, Mengurai Kompleksitas Hak Asasi Manusia: Kajian Multi Perspektif (Yogyakarta: Pusat Studi Hak Asasi Manusia, 2017).

80 Cesare Lombroso, Mary Gibson \& Nicole Hahn Rafter, Criminal Man (Duke: Duke University Press, 2016).

81 MK decision number 21/PUU-VI/2008; Cesare Lombroso \& Henry Pomeroy Horton, Crime, its Causes and Remedies (Little, Brown and Company Press, 1918). Another paper edited by Cesare Lombroso, Mary Gibson \& Nicole Hahn Rafter, supra note 80. The opinion of Garofalo can be seen in Raffaele Garofallo \& Robert Wyness Millar, Criminology (Little Brown and Company Press, 1914).

82 The opinion of Achmad Ali in MK Decision Number 21/PUU-VI/2008; See also Achmad Ali, 50 Tahun, Usia Prof. Dr. Achmad Ali, S.H., M.H.: Karya Pilihannya dan Komentar Berbagai Kalangan tentang Achmad Ali (Penerbit S.N., 2012). 
and freedoms of others, and to fulfill fair indictment regarding moral, religious values, security, and public order in a democratic society. ${ }^{83}$

Several countries besides Indonesia that remain applying the death penalty are Iran, Saudi Arabia, China, and United States. In the case of Iran and Saudi Arabia, the state consistently applies Islamic law. ${ }^{84}$ In the provisions of Islamic law, the principle of justice is based on respect for people's right to life. ${ }^{85}$ Humans are caliphs on earth. The value of human life is very high. Humans cannot arbitrarily end other people's lives. ${ }^{86}$ In China, the death penalty is mostly based on the principle of violating state power. Thus, throughout history, the death penalty in China has been mostly due to accusations of treason against the state, such as the abuse of state power by corruption, not being dominated by other human killings. ${ }^{87}$

The death penalty applied in the United States is not the same across states. Some states still have the death penalty, but others no longer have it. The death penalty is often imposed by the Global South countries, while most North Countries no longer have the death penalty. ${ }^{88}$ Meanwhile, in Indonesia, the death penalty is applied to people or criminals classified as large and sadistic, such as terrorists, premeditated murder, and drug traffickers. However, the penalty is executed after going through a long investigation and inquiry until it turned out in a formal juridical manner.

83 See the opinion of Achmad Ali in MK Decision Number 21/PUU-VI/2008; Ibid.

${ }^{84}$ Mohammadrasool Yadegarfard, "How are Iranian Gay Men Coping with Systematic Suppression Under Islamic Law? A Qualitative Study” (2019) Sex Cult. Bahman Baktiari, "Iran: Shari'a politics and the transformation of Islamic law" in Sharia Polit Islam Law Soc Mod World (2011). Mary Carter Duncan, "Playing by Their Rules: The Death Penalty and Foreigners in Saudi Arabia" (2014) Ga J Int Comp Law.

85 Michael Mumisa, "Sharia law and the death penalty Would abolition of the death penalty be unfaithful to the message of Islam?" (2015). Hatta, supra note 61.

86 Ari Darmastuti, "Kontroversi Hukuman Mati", Lampung Post (2015).

87 In Islamic countries, the death penalty imposed on a person can be avoided if the victim's family forgives the murderer's actions - the first right to forgive rests with the family of the murdered, not with the state. Even though Indonesia is not an Islamic country, Indonesia still applies the assumption in Islamic countries, and some differences have been explained in the previous discussion; Ibid.

88 Ibid. 


\section{Efforts to Abolish the Death Penalty in Indonesia}

According to its opponents, the death penalty cannot be approached from a normative perspective. However, throughout Indonesia's history, the death penalty application has proven as a regime political instrument absent from democracy. The formation of various legal provisions (al-taqnin) that apply the death penalty brought the Indonesian people closer to understanding the nature of the power regime behind the legislation. It is no longer about the essence of the death penalty. Meanwhile, the death penalty as an instrument considered by some to reduce crime rates proved otherwise. ${ }^{89}$

According to the abolitionist, the death penalty has never been successful and could restore a situation disturbed by a crime. Maintaining the application of the death penalty in a positive legal approach cannot be justified. All historical frameworks on the application of the death penalty in national law since the Dutch colonial period until the formation of new legal products only hints at the nature of state power rather than legal aspects in the framework of overcoming various forms of crime, such as Narcotics Law 22/1997, Psychotropics Law 05/1997, Eradicating Corruption Law 31/1999, Human Rights Courts Law 26/2000, and Eradicating Terrorism Law 15/2003. The death penalty appears in political steps, both threatening political forces in society and gaining political support. ${ }^{90}$ It is difficult to find the right relationship and relevance between applying the death penalty and crime, even to prove a deterrence effect against the perpetrators of crime. In this context, the death penalty is not seen as an essential functional instrument for maintaining social harmony.

${ }^{89}$ Usman Hamid, "Hukuman Mati Bukan Sekadar Penerapan Hukum Positif", Kompas (2013).; Adian Husaini, Rajam dalam Arus Budaya Syahwat: Penerapan Hukum Rajam di Indonesia dalam Tinjauan Syariat Islam, Hukum Positif dan Politik Global (Pustaka al-Kautsar, 2011).

90 Various arguments have emerged showing the effectiveness of the death penalty implementation in an ethical and moral framework. The desire to retaliate against the perpetrator of the crime has preceded the trial process of the dead suspects. The proponent group believes that the balance will be disturbed by the occurrence of the crime. The balance desire is the desire for optimum retaliation through judicial legitimacy. Hamid, supra note 89. 
On the contrary, in history, it can be found that the concentration and harmony of power is the room space for the death penalty. ${ }^{91}$

Based on the preceding considerations, the abolitionist still insist that the death penalty must be rejected or, at least, revisited, considering several reasons. First, Indonesia's character of positive legal reform has not shown an impartial judicial system and a clean apparatus. The dilapidation of the judicial system can increase the chances of the death penalty from an unfair trial. ${ }^{92}$ Second, there is no scientific evidence that the death penalty can reduce certain crimes from the sociological aspect. Therefore, it could not be a determinant factor in causing a deterrent effect compared to other types of punishment. A United Nations study on the relationship between the death penalty and the rate of murder between 1988-2018 has concluded that the death penalty does not influence the crime of murder compared to other punishments such as life sentences. ${ }^{93}$ Third, the increase in drug crimes, terrorism, or other crimes is caused by the absence of the death penalty and other structural problems such as poverty and corrupt law/state apparatus. Even for terrorism crimes, the death penalty is generally a determinant factor that strengthens the recurrence of actions in the future. The death penalty has even become ideological ammunition to enhance the radicalism and militancy of the perpetrators and their groups. ${ }^{94}$ Fourth, the death penalty in Indonesia so far is still class bias and discriminatory, where it has never reached an elite group whose crimes can generally be categorized as serious or extraordinary crimes. As a result, the perpetrators of corruption, gross human rights violations with a much

91 Ibid.

92 Suryadi A Radjab \& Ismail Hasani, Indonesia, Hilangnya Rasa Aman: Hak Asasi Manusia dan Transisi Politik Indonesia (Jakarta: PBHI dan The Asia Foundation Group Press, 2012). Yazid, supra note 65.

93 Jon Yorke, Against the Death Penalty: International Initiative and Implication (Ashgate: Ashgate Publishing Ltd., 2019). Peter Hodgkinson \& William Schabas, Capital Punishment: Strategies for Abolition (Cambridge: Cambridge University Press, 2014).

94 Zuly Qadir, Islam Syari'ah vis a vis Negara: Ideologi Gerakan Politik di Indonesia (Jakarta: Pustaka Pelajar, 2017). Afadlal, Endang Turmudi \& M Riza Sihbudi, Islam dan Radikalisme di Indonesia (Jakarta: Lembaga Ilmu Pengetahuan Indonesia-LIPI dan Yayasan Obor Press, 2015). 
higher number of victims, and detrimental to the economy of many people have never been sentenced to death. ${ }^{95}$ Fifth, the application of the death penalty also shows the contradictive Indonesian legal politics. In fact, since the reformation era, there have been various changes in law and state policy. Although the death penalty is still attached to several products of national law, legal reform also emphasizes the importance of the right to life. Article 28I(1) of the 1945 Constitution is concrete evidence of this argument. ${ }^{96}$ Sixth, the government's political stance on the death penalty is also ambiguous. For example, the Indonesian government has often made persistent requests to the government of Saudi Arabia not to carry out the death penalty for its Indonesian citizens abroad for humanitarian reasons. However, it does not happen in the death penalty cases against Indonesian citizens and foreigners in Indonesia. ${ }^{97}$

Human Rights activists urge the death penalty to be reviewed. The death penalty has also cut off the chance for the perpetrator to repent. There is a primary objection expressed in the constitution, which guarantees the right to life of every human being. The justice indictment is the fundamental tool to reduce the number of crimes. Even though many articles contain the death penalty, the crime rate remains high. ${ }^{98}$ The death penalty results in a cycle of violence, impacting trauma. Based on a human rights perspective, if violence is reciprocated with violence, the result is a continuous cycle of crimes. It is different if violence is reciprocated by

95 Eko Prasetyo, Demokrasi Tidak Untuk Rakyat (Yogyakarta: Resist Book press, 2005).

96 Yasraf Amir Pialang, Transpolitika: Dinamika Politik di dalam Era Virtualitas (Penerbit Jalasutra, 2015). Penerbit Buku Kompas, Negara Minus Nurani (Jakarta: Kompas Gramedia, 2019).

97 Saiful Mujani, Muslim Demokrat: Islam, Budaya Demokrasi, dan Partisipasi Politik di Indonesia Pasca Orde Baru (Jakarta: Gramedia Pustakka Utama, 2017).

98 In Islam, Fiqh is taught, which is explained life regulation regardless of its background. So, for example, when someone makes a mistake, fundamental rights must be prioritized before the penalty. The basic human right taught in Fiqh contain life teachings, namely, the right to life, the right to embrace religion, think, have a family, and maintain honor; Adnan Buyung Nasution, Ramadhan KH \& Nina Pane Budiarto, Pergulatan Tanpa Henti: Pabit Getir Merintis Demokrasi (Jakarta: Penerbit Aksara Karunia, 2014). 
mutual forgiveness and loving efforts. ${ }^{99}$ Amendments to the national law are an entry point for the abolition of the death penalty. As the constitution has given birth to recognizing that the right to life cannot be reduced for any reason, abolishing the penalty is a constitutional obligation.

\section{E. The Current Death Penalty in Indonesia}

Amid the global trend towards a moratorium on the death penalty, this practice is becoming increasingly prevalent in Indonesia. ${ }^{100}$ Even though it often creates controversy, the imposition of the death penalty in Indonesia continues to exist and is justified in a formal juridical manner. It refers to several articles in the Criminal Code (KUHP) which contain and support the death penalty. ${ }^{101}$ There are also at least seven specific laws and regulations that include the threat of the death penalty, namely Narcotics Law 22/1997, Psychotropics Law 5/1997, Eradication of Terrorism Law 15/2003, Eradication of Corruption Law 31/1999, Human Rights Courts Law 26/2000, and State Intelligence Law 17/2011. ${ }^{102}$ Therefore, the death penalty is getting extra permanent in the statutory system in Indonesia. ${ }^{103}$ Even in the last twenty years, the death penalty application has peaked its

99 Kompas, "Eksekusi Hukuman Mati Harus Dikaji Ulang", Kompas (28 November 2018).

${ }^{100}$ Nathaniel Persily, Jack Kitrim \& Patrick J Egan, Public Opinion and Constitutional Controversy (Oxford: Oxford University Press, 2008).

${ }^{101}$ For example, treason to assassinate the Head of State (Article 104), premeditated murder in Articles 340 and 365(4), inviting foreign countries to attack Indonesia in Article 111(2), providing assistance to the enemy when the state is at war in Article 124(3), killing the head of friendly country in Article 140(1), violent theft by two or more which causes another person to be seriously injured or dead in Article 365(4), piracy at sea, on the coast, and in rivers that cause people to die in Article 444, encouraging riots, rebellion between workers in state defense institutions in time of war in Article 124, committing fraud in the information of the armed forces when the state is in a war in Articles 127 and 129, and exertion by weight in Article 368(2). See Bambang Waluyo, Pidana dan Pemidanaan (Jakarta: Sinar Grafika, 2008).

102 Badan Pekerja Kontras, supra note 22.

${ }^{103}$ Sudi Prayitno, "Dilema Hukuman Mati", (2020), online: Legalitas <http://www.legalitas.org/?q=content/dilema-hukuman-mati >. Craig Haney, Death by Design: Capital Punishment as Social Psychological System (Oxford: Oxford University Press, 2005). 
momentum along with the increasing frequency of claims by human rights activists to abolish the death penalty in Indonesia.

From 1945 to 2000, Indonesia executed 16 persons. ${ }^{104}$ This number is relatively small compared to the last 20 years (from 2000 to 2020), which amounted to 23 persons. ${ }^{105}$ According to Amnesty International's records, it is classified as one of the countries with relatively "sold out" death sentences compared to other countries in the world. ${ }^{106}$ The execution of the death penalty in Indonesia shows an increasing trend in the last decade. In the context of democracy, laws were enacted after the agreement between the House of Representatives and the President. Laws were made in a process of legislation, under democratic mechanism. ${ }^{107}$ The death penalty in Indonesia has been attempted through political negotiations and resulted in democratic decisions or policies. Nevertheless, the death penalty persists and is maintained within the Indonesian legislation even though it has to go through a long struggle to face various interests that insist on rejecting its application in Indonesia.

\section{CONCLUSION}

The death penalty in Indonesia originates from a series of democratization conceded under the legislative powers. The fact democratization reveals that the stipulation of the death penalty in several laws in Indonesia has been thoroughly discussed in the legislative institutions (the House of Representatives and the President). The death penalty has been agreed

${ }^{104}$ Yusran Yunus, "Ini Daftar Terpidana Mati di Indonesia Yang Sudah Dieksekusi", (2015), online: Kabar24 <https://kabar24.bisnis.com/read/20150121/16/393285/inidaftar-terpidana-mati-di-indonesia-yang-sudah-dieksekusi>.

105 Discussion on Death Penalty Contemporary Challenges, Delegation of European Commission and Department of Philosophy Faculty of Humanities at the University of Indonesia, by William Schabas (Jakarta, 2004).

${ }^{106}$ Prayitno, supra note 103. Muhammad Abu Hasan, Abkam al-Jarimah wa al-'Uqubah fi al-Syariah al-Islamiyah: Dirasah Muqaranah (California: University of California Press, 2007).

${ }^{107}$ In this context, democracy in Indonesia is understood as a primary system in community and state life and a fundamental state principle that provides direction for the role of society in administering the state as the highest organization. See Mahfud MD, Hukum dan Pilar-pilar Demokrasi (Yogyakarta: Gema Media, 1999). 
upon and decided through political and legal aspects so that the adoption in the Indonesian penal system must be respected and obeyed. While the negative impression deals with human rights, the imposition of the death penalty in Indonesia is still maintained, with specific and selective applications. Specific means that the death penalty is applied to perpetrators of serious crimes, such as corruptors, drug kingpins, terrorists, gross human rights actors, and premeditated murders. The means of selection is that a convict must be very convincingly proven in court and accepted in a formal judiciary.

\section{ACKNOWLEDGMENTS}

None.

\section{COMPETING INTEREST}

The authors declared that they have no competing interests.

\section{REFERENCES}

Adnan Buyung Nasution, Ramadhan KH \& Nina Pane Budiarto, Pergulatan Tanpa Henti: Pahit Getir Merintis Demokrasi (Jakarta: Penerbit Aksara Karunia, 2014).

Afadlal, Endang Turmudi \& M Riza Sihbudi, Islam dan Radikalisme di Indonesia (Jakarta: Lembaga Ilmu Pengetahuan Indonesia-LIPI dan Yayasan Obor Press, 2015).

Ali, Achmad, 50 Tabun, Usia Prof. Dr. Achmad Ali, S.H., M.H.: Karya Pilibannya dan Komentar Berbagai Kalangan tentang Achmad Ali (Penerbit S.N., 2012).

Alkostar, Artidjo, Pengadilan HAM, Indonesia dan Peradaban (Yogyakarta: PUSHAMM-UII, 2014).

Ankar, Casten, Determinants of the Death Penalty; Comparative Study of the World (London: Routledge Press, 2014). 
Anwar, Yesmil, Pembaruan Hukum Pidana: Reformasi Hukum (Jakarta: Penerbit Grasindo, 2018).

Ardani, Nur Afif, Sulfi Amalia \& Rooseno Hertanto, "Relativisme Budaya Dalam Hak Asasi Manusia” (2017) 14:1 30-46.

Arief, Barda Nawawi, Kebijakan dalam Penanggulangan Kejahatan dengan Pidana Penjara (Semarang: Ananta, 1994).

Badan Pekerja Kontras, Praktek Hukuman Mati di Indonesia: Laporan Hasil Penelitian (Jakarta: Kontras, 2017).

Baktiari, Bahman, "Iran: Shari'a politics and the transformation of Islamic law" in Sharia Polit Islam Law Soc Mod World (2011).

BBC, "Negara mana yang masih menerapkan hukuman mati? Bagaimana dengan Indonesia?”, (2018), online: BBC Nerws Indones <https://www. bbc.com/indonesia/dunia-45859508>.

Brooks, Thom, Hegel's Philosophy of Right (Wiley-Blackwell, 2011).

Cesare Lombroso, Mary Gibson \& Nicole Hahn Rafter, Criminal Man (Duke: Duke University Press, 2016).

Cesare Lombroso \& Henry Pomeroy Horton, Crime, its Causes and Remedies (Little, Brown and Company Press, 1918).

Clarkson, Christoper MV, Understanding Criminal Law (Sweet and Maxwell Publisher, 2005).

Darmastuti, Ari, “Kontroversi Hukuman Mati”, Lampung Post (2015).

Darmawan, Iwan, "Perkembangan dan Pergeseran Pemidanaan" (2015) 1:2 Palar Pakuan Law Rev.

David CBrody, James R Acker \& Wayne A Logan, Criminal Law (US: Johns and Bartlett Publishers, 2001).

David J Cornwell \& Tony Cameron, Criminal Punishment and Restorative Justice: Past, Present, and Future Perspective (United States: Waterside Press, 2016). 
Dosen, Risman et al, "Polemik Pemidanaan (Kontroversi Faham Abolisionis Dan Retensionis)” (2018) 1:2 J Syariah Huk Islam 158165 .

Duncan, Mary Carter, "Playing by Their Rules: The Death Penalty and Foreigners in Saudi Arabia" (2014) Ga J Int Comp Law.

Gibbs, Jack P, “The Death Penalty, Retribution and Penal Policy” (1978) 69:3 J Crim Law Criminol 1973- 291.

Gray, Cavender, "Justice, Sanctioning, and the Justice Model" (1984) Criminology.

Gunarto, Marcus Priyo, "Sikap Memidana yang Berorientasi pada Tujuan Pemidanaan” (2009) 21:1 Mimb Huk.

Hall, Jerome, General Principal of Criminal Law (The Lawbook Exchange Ltd. Publisher, 2015).

Hamid, Usman, "Hukuman Mati Bukan Sekadar Penerapan Hukum Positif”, Kompas (2013).

Hammel, Andrew, Ending the death penalty: The European experience in global perspective (Palgrave Macmillan, 2010).

Haney, Craig, Death by Design: Capital Punishment as Social Psychological System (Oxford: Oxford University Press, 2005).

Harahap, Krisna, Pemberantasan Korupsi, Jalan Tiada Ujung (Penerbit Grafitri, 2016).

Hasan, Muhammad Abu, Ahkam al-Jarimah wa al-'Uqubah fi al-Syari'ah al-Islamiyah: Dirasah Muqaranah (California: University of California Press, 2007).

Hatta, Mohammad, Mohammad Hatta (Jakarta: Tintamas, 1986).

Hatta, Muhammad, "Perdebatan Hukuman Mati di Indonesia: Suatu Kajian Perbandingan Hukum Islam dengan Hukum Pidana Indonesia" (2012) 36:2 MIQOT J Ilmu-Ilmu Keislam.

Hegel, Georg Wilhelm Fredrich, Hegel: Elements of the Philosophy of Right (Cambridge University Press, 1991). 
Hiariej, Eddy OS, Prinsip-Prinsip Hukum Pidana (Yogyakarta: Cahaya Atma Pustaka, 2016).

Hood, Roger G, "The Death Penalty: A Worldwide Perspective" 225.

Husaini, Adian, Rajam dalam Arus Budaya Syahwat: Penerapan Hukum Rajam di Indonesia dalam Tinjauan Syariat Islam, Hukum Positif dan Politik Global (Pustaka al-Kautsar, 2011).

ICJR, "Hukuman Mati di Indonesia dari Masa Ke Masa”, (2017), online: $<$ https://icjr.or.id/hukuman-mati-di-indonesia-dari-masa-ke-masa/>.

Institute, Spectrum, Terorisme Ditengah Arus Global Demokrasi (Penerbit Spectrum, 2016).

Kholiq, M Abdul \& Ari Wibowo, "Penerapan Teori Tujuan Pemidanaan dalam Perkara Kekerasan” (2016) 23:2 186-205.

Khoemaeni, Syamsul Anwar, "84 Negara Kecuali Indonesia yang Hapus Hukuman Mati”, (2015), online: Okenews <https://nasional. okezone.com/read/2015/04/28/337/1141582/84-negara-kecualiindonesia-yang-hapus-hukuman-mati>.

Kompas, "Eksekusi Hukuman Mati Harus Dikaji Ulang", Kompas (28 November 2018).

Kompas, Penerbit Buku, Negara Minus Nurani (Jakarta: Kompas Gramedia, 2019).

Kurnia, Titon Slamet, Hak atas Derajat Kesehatan Optimal Sebagai HAM di Indonesia (Bandung: Penerbit Alumni, 2017).

Lacey, Nicola, State Punishment: Political Principal and Community Values (Routledge: Routledge University Press, 1994).

Liverani, Mario, "Hammurabi of Babylon" in Anc East (Routledge, 2020) 264.

Maiwan, Mohammad, "Memahami Teori-Teori Etika: Cakrawala dan Pandangan” (2018) J Uiversitas Negeri Jkt 193-215.

Mandery, Evan J, Capital Punishment: A Balanced Examination (Jones and Bartlett Publishers, 2014). 
Marbun, BN, Kamus Hukum Indonesia (Jakarta: Pustaka Sinar Harapan, 2016).

Marwati Juned Pusponegoro et al, Sejarah Nasional Indonesia: Kemunculan Penjajahan di Indonesia (Jakarta: Penerbit PT Balai Pustaka, 2008).

MD, Mahfud, Hukum dan Pilar-pilar Demokrasi (Yogyakarta: Gema Media, 1999).

MD, Mahfudh, Membangun Politik Hukum, Menegakkan Konstitusi (Jakarta: LP3ES, 2006).

Mieroop, Marc Van De, King Hammurabi of Babylon: A Biography (John Wiley and Sons, 2008).

Mitchell, Barry \& Julian V Roberts, "Sentencing for Murder: Exploring Public Knowledge and Public Opinion in England and Wales" (2012) 52:1 Br J Criminol 141-158.

Mujani, Saiful, Muslim Demokrat: Islam, Budaya Demokrasi, dan Partisipasi Politik di Indonesia Pasca Orde Baru (Jakarta: Gramedia Pustakka Utama, 2017).

Mumisa, Michael, "Sharia law and the death penalty Would abolition of the death penalty be unfaithful to the message of Islam?" (2015).

Muryani, Maria Anna \& Noor Rosyida, "The Concept of Death Penalty in a Pancasila State (Perspective of Official Religion in Indonesia)" (2020) 2:2 Walisongo Law Rev Walrev 131.

Nasution, Adnan Buyung, Arus Pemikiran Konstitusionalisme: Hukum dan Peradilan (Jakarta: Penerbit KATA, 2017).

Nathaniel Persily, Jack Kitrim \& Patrick J Egan, Public Opinion and Constitutional Controversy (Oxford: Oxford University Press, 2008).

Norval Morris \& David J Rothman, The Oxford History of the Prison: The Practice of Punishment in Western Society (Oxford: Oxford University Press, 1998).

Nowak, Manfred, United Nation Covenant on Civil and Political Rights, ICCPR Commentary (Leiden: N.P. Engel Publisher, 2005). 
Others, Benyamin and, Prisons or Crime Prevention (England: Little Blue Book CO, 1977).

Peter Hodgkinson \& William Schabas, Capital Punishment: Strategies for Abolition (Cambridge: Cambridge University Press, 2014).

Pialang, Yasraf Amir, Transpolitika: Dinamika Politik di dalam Era Virtualitas (Penerbit Jalasutra, 2015).

Poernomo, Bambang, Asas-asas Hukum Pidana (Yogyakarta: Ghalia Indonesia, 1995).

Prasetyo, Eko, Demokrasi Tidak Untuk Rakyat (Yogyakarta: Resist Book press, 2005).

Prayitno, Sudi, "Dilema Hukuman Mati", (2020), online: Legalitas <http://www.legalitas.org/?q=content/dilema-hukuman-mati >.

Prodjodikoro, Wiryono, Asas-Asas Hukum Pidana di Indonesia (Bandung: Eresco, 1989).

Purwanto, Wawan H, Kontroversi Seputar Hukuman Mati Amrozi CS (Jakarta: Cipta Mandiri Bangsa, 2008).

Qadir, Zuly, Islam Syariah vis a vis Negara: Ideologi Gerakan Politik di Indonesia (Jakarta: Pustaka Pelajar, 2017).

Raffaele Garofallo \& Robert Wyness Millar, Criminology (Little Brown and Company Press, 1914).

Rasjidi, Lili, Dasar-dasar Filsafat Hukum (Bandung: Citra Aditya Bakti, 1993).

Reitzenstein-Ronning, Christian, "Performing justice: the penal code of Constantine the Great" (2015) 265-288.

Romli Atmasasmita \& Agus Takariawan, Reformasi Hukum, Hak Asasi Manusia dan Penegakan Hukum (Mandar Maju, 2011).

Saepullah, Asep, "Konsep Utilitarianisme John Stuart Mill: Relevansinya terhadap Ilmu-ilmu atau Pemikiran Keislaman” (2020) 11:2 Aqlania J Filsafat Dan Teol Islam 243-261. 
Sahetapy, JE, Suatu Studi Khusus Mengenai Ancaman Pidana Mati terhadap Pembunuan Berencana.

Saputra, Andi, “6 Orang Dihukum Mati Sepanjang Februari 2020, Ada yang Nangis Mewek", (2020), online: Detiknews <https:// news.detik.com/berita/d-4920456/6-orang-dihukum-mati-sepanjangfebruari-2020-ada-yang-nangis-mewek>.

Sarat, Austin \& Jürgen Martschukat, Is the death penalty dying?: European and American perspectives (Cambridge University Press, 2011).

Sastrawidjaja, Sofjan, Hukum Pidana: Asas Hukum Pidana sampai Dengan Alasan Peniadaan Pidana (Bandung: Amrico, 1995).

Schabas, William, The Abolition of the Death Penalty in International Law (Cambridge: Cambridge University Press, 2002).

Schabas, William, Discussion on Death Penalty Contemporary Challenges, Delegation of European Commission and Department of Philosophy Faculty of Humanities University of Indonesia, by William Schabas (Jakarta, 2004).

Supardi, Kajian Kritis Pro dan Kontra Pelaksanaan Hukuman Mati Di Indonesia, Khususnya Terhadap Kejabatan Narkoba (Jakarta: Badan Narkotika Nasional Republik Indonesia, 2015).

Suparni, Niniek, Tindak Pidana Subversi: Suatu Tinjauan Yuridis (Jakarta: Sinar Grafika, 1991).

Suryadi A Radjab \& Ismail Hasani, Indonesia, Hilangnya Rasa Aman: Hak Asasi Manusia dan Transisi Politik Indonesia (Jakarta: PBHI dan The Asia Foundation Group Press, 2012).

Tahirulqadri, Muhammad, Islamic Philosophy of Punishments (Minhaj Quran Publication).

Tobias, JJ, Crimes and Industrial Society in the Nineteenth Century (England: Penguin Book Press, 1973).

UII, Mengurai Kompleksitas Hak Asasi Manusia: Kajian Multi Perspektif (Yogyakarta: Pusat Studi Hak Asasi Manusia, 2017).

Usman, “Analisis Perkembangan Teori Hukum Pidana” J Ilmu Huk. 
Waluyo, Bambang, Pidana dan Pemidanaan (Jakarta: Sinar Grafika, 2008).

Widodo, Rusman, "Konfigurasi Pertarungan Abolisionisme Versus Retensionisme dalam Diskursus Keberadaan Lembaga Pidana Mati di Tingkat Global dan Nasional” (2012) 8 J Komnas HAM 315-348.

Wilson, William, Criminal Law: Doctrine and Theory (Longman: Longman Publisher, 2003).

Yadegarfard, Mohammadrasool, "How are Iranian Gay Men Coping with Systematic Suppression Under Islamic Law? A Qualitative Study" (2019) Sex Cult.

Yahya, Imam, "Hukuman Mati dalam Perspektif Sejarah" (2013) 23:April Al-Ahkam J Pemikir Huk Islam 81-98.

Yazid, Abdullah, "Meninjau Ulang Hukuman Mati”, (2019), online: $<$ http://www.averroes.or.id/opinion/meninjau-ulang-hukuman-mati. html>.

Yorke, Jon, Against the Death Penalty: International Initiative and Implication (Ashgate: Ashgate Publishing Ltd., 2019).

Yunus, Yusran, "Ini Daftar Terpidana Mati di Indonesia Yang Sudah Dieksekusi”, (2015), online: Kabar24 <https://kabar24.bisnis.com/ $\mathrm{read} / 20150121 / 16 / 393285 /$ ini-daftar-terpidana-mati-di-indonesiayang-sudah-dieksekusi >.

Zaibert, Leo, Punishment and Retribution (Ashgate: Ashgate Publishing Ltd, 2016).

Zohair Husain, Mir \& Stephen E Costanza, "Code of Hammurabi" in Encycl Correct (John Wiley \& Sons, Inc., 2017) 1.

Zulfa, Eva Achjani, "Pergeseran Paradigma Pemidanaan di Indonesia" (2017) 36:3 J Huk Pembang 389. 
150 | Death Penalty in Indonesia: Revisiting the Debate Between the Retentionist and the Abolitionist 